\title{
STATUS OF FINANCIAL INCLUSION IN HILLY RURAL AREAS OF UTTARAKHAND: A COMPARATIVE STUDY OF PAURI, CHAMOLI AND RUDRAPRAYAG DISTRICT
}

\author{
Prashant Kandari* \\ Department of Economics, H.N.B. Garhwal University (A Central University), Srinagar Garhwal, \\ Uttarakhand
}

*Corresponding Author Email Id: kandari1980@gmail.com

Receive: 29.9.2020; Revised: 12.10.2020; Accepted: 29.10.2020

(C)Society for Himalayan Action Research and Development

\begin{abstract}
Hill Rural regions of Uttarakhand are inherent part of the state and were the prominent reason on the basis of which Uttarakhand state was carved out of Uttar Pradesh. Unfortunately the underdevelopment of these regions due to the aspect of 'Area Deprivation' associated with them has led to emergence of prominent problems like unemployment, lack of income generating opportunities and poverty leading further to a major problem of rural outmigration from them. To raise the economic condition of households of these regions it is important to enhance the income generating opportunities and to provide financial services which could cover up the majority of population with the social security net. The major way out to achieve them is through increase in financial inclusion. The present study through help of primary data examines the level of financial inclusion in the hill rural regions of Uttarakhand for which FII is computed on the basis of 4 dimensions of financial inclusion. The FII of the rural regions of development blocks of hill districts is compared with the FII of the all Indian rural households to examine the status of financial exclusion in hill rural regions of the state.
\end{abstract}

Keywords: Financial Inclusion, Index, Hilly rural region, Area Deprivation, financial

\section{Introduction (The Background scenario)}

Uttarakhand was carved out of Uttar Pradesh state 20 years back due to prominent issue of failure of outreach or extension of Urban and rural development policies and programs of state government up to Hilly areas of Uttarakhand region. This along with other such related issues lead to emergence of demand of a separate state. This demand was voiced mainly to come up with a governance body that could concentrate mainly on these hill regions which demands separate attention and separate approach for their growth and development. In year 2000 Uttarakhand was separated from Uttar Pradesh to help avoid the dichotomy issues in development in case of two states which are very different from each other. This formation of new state of Uttarakhand was like a dream come true for its inhabitants but soon the dream started to fade away in the darkness of reality. This observed harsh reality came out with the realization of emergence of a new dichotomy that has emerged within the new formed state of Uttarakhand. This dichotomy was observed in terms of a development gulf created between the hill and plain districts of the state. Uttarakhand is comprised of 13 districts out of which 3 are plain districts while 10 districts represent hill districts. The hill districts of Uttarakhand lag way behind the plain districts of the state in terms of various development indicators. Further if we compare the rural and urban region of hill districts this divide in development is also substantial and reflects the state of area deprivation among the rural regions 
of hill districts. These hill rural regions of Uttarakhand state are inhabited by majority of population of the state and have always been marked with problems. The problems of these regions are very different from that of plain areas of the state; some of the prominent ones of these problems include the poor infrastructure development be it in area of transport network, health sector or education sector (mainly under public sector). These structural problems have channelized the emergence and existence of other major problems among which Migration is the prominent one which has deprived the state of its human resource. This trend of loss of human resource has led to serious regional imbalance within the state which indicates the movement of state in unsustainable pathway of development. The migration has been so prominent from these regions that the total population of many villages have come down to double digit and further many villages in hill regions of the state have got completely devoid of human existence; such villages in the state are now termed as ghost villages. Thus this imbalance has enhanced the inequality in development among these hill and plains regions of the state.

The area deprivation in hill rural regions of the state has led to failure in agricultural and industrial development which has resulted in lack of employment and income generating opportunities. The lack of income and employment opportunities is one of the major reasons for the huge amount of migration from these regions. Many policies based on "specific issue based action approach" have been implemented to deal with various issues/problems, with no effect. Some policies targeted the issue of migration, few focused on education, others on agriculture, health and other issues. Even while targeting a particular problem the policy framed for dealing with all the issues lacked the holistic approach which has inhibited the positive impacts of such policy actions. Financial inclusion is one such policy initiative which was targeted mainly in these regions of the state. In this context, policy approach towards enhancing financial inclusion could play holistic role in regional development, if implemented effectively. Financial inclusion does not only mean having bank account, or provision of credit alone, it is a multi-fact concept and should include the provision of Priority Sector Advances targeting the weaker section of population along with all other services, ranging from insurance, remittance facilities etc. The financial inclusion with increased penetration on one side along with increase in savings could play significant part by leading to a credit drive. The credit flow could further be enhanced by firstly through ease of accessibility to priority sector lending by financial institutions and secondly through ease of delivery of credit by financial institutions. In such credit drive the credit starved poor households, new budding entrepreneurs, micro small and medium sized Enterprises and farmers could be targeted. The other factor which raises the significance of enhancing financial inclusion in hill rural regions of the state is significant role of women in the economy of these regions. Financial inclusion could facilitate the women with greater control over their financial lives which could further provide them with avenues to not only assist their families from falling in to the trap of poverty but also to come out of poverty. Financial inclusion would facilitate women with larger income and employment opportunities in various productive economic activities simultaneously protecting them from being forced in to informal sector which could avoid the potential exploitation towards which they are largely vulnerable. The financial inclusion could also assist the various women led SHGs in these regions with easing the availability and accessibility of Micro Finance. The facilitating of social security through enhancing financial inclusion is also essential for improving the living standards of the residents of these deprived regions of the state. At large financial inclusion through the working of multiplier effect could increase the economic output and growth along with helping in attaining the objective of poverty eradication and reduction of income and regional inequality in these deprived regions of the state. 


\section{Financial Inclusion}

\section{(i) Indian Scenario}

The history of financial inclusion marks the nationalization of Life Insurance companies in 1956 followed up by the nationalization of banks in 1969 and 1980 which were followed by some policies such as social banking policy, priority sector lending aimed to enhance the financial inclusion mainly in rural regions. The major drive of financial inclusion was launched in August, 2014 which was named as the Pradhan Mantri Jan Dhan Yojana (PMJDY). PMJDY aims to deliver banking services to every unbanked household and as per Ministry of Finance, GoI the Yojana is based on the guiding principles of banking the unbanked, securing the unsecured, funding the unfunded and serving unserved and underserved areas. In case of adversely/remote areas located households the intermediaries known as Business Correspondents (BC's) will be the executors and act as the face of these banking \& financial institutions in dealing with end-users. In the last quarter of 2016, India through demonetization aimed at curbing black money, reducing tax evasion and moving country through cashless economy, for promoting digital economy. Following it NPCI launched Bharat Interface for Money (BHIM), which is a payment app, to move towards cashless payments through mobile phones.

As per Ministry of Finance, GoI, since the inception of PMJDY, over 35 crore new accounts have been opened and over Rs. 96,000 crore has been deposited by the newly banked people in the formal banking system. The number of operative
PMJDY accounts has increased from 17.01 crore on March'17 to 27.54 crore on March'19. There are 53\% women Jan-Dhan account holders and 59\% Jan-Dhan accounts in rural and semi-urban areas. A total of 27.91 crore RuPay debit cards have been issued till 30.03.2019 to PMJDY account-holders. In case of loan disbursal 72983 entrepreneurs benefited under Stand Up India scheme, as on 31.03.2019. Further three ambitious Jan Suraksha Schemes or Social Security Schemes namely (a) Pradhan Mantri Suraksha Bima Yojana and (b) Pradhan Mantri Jeevan Jyoti Yojana and (c) Atal Pension Yojana pertaining to Insurance and Pension Sector were announced for providing life $\&$ accident risk insurance and social security at a very affordable cost for person holding bank or post office account.

\section{(i) In Uttarakhand}

Uttarakhand state has performed better in financial inclusion on few parameters among which one is number of bank branches per average population. On the basis of census 2011 population at the present time the average population size per bank branch in Uttarakhand state is 4263 which is better than the National average population of 11000 per bank branch. Further the degree of financial inclusion varies considerably among the different districts of Uttarakhand state. The following table 1 depicts the state of financial inclusion on the basis of few parameters: 
Table 1: State of financial inclusion in Uttarakhand

\begin{tabular}{|c|c|c|c|c|c|c|}
\hline $\begin{array}{c}\text { S.N } \\
\text { o }\end{array}$ & District Name & $\begin{array}{c}\text { Bank } \\
\text { branches } \\
\text { Dec-19 }\end{array}$ & $\begin{array}{c}\text { Total } \\
\text { Bank branch per } \\
\text { average population }\end{array}$ & $\begin{array}{c}\text { Total } \\
\text { Deposit (in } \\
\text { Crore) }\end{array}$ & $\begin{array}{c}\text { advances } \\
\text { (in Crore) }\end{array}$ & $\begin{array}{c}\text { C: D } \\
\text { Ratio }\end{array}$ \\
\hline 1 & Dehradun & 583 & 2910 & 53798 & 22517 & 42 \\
\hline 2 & Uttarakashi & 64 & 5158 & 2216 & 910 & 41 \\
\hline 3 & Haridwar & 283 & 6680 & 20311 & 16489 & 81 \\
\hline 4 & Tehri & 134 & 4619 & 5002 & 1259 & 25 \\
\hline 5 & Pauri & 197 & 3489 & 8506 & 2031 & 24 \\
\hline 6 & Chamoli & 95 & 4122 & 3462 & 2565 & 74 \\
\hline 7 & Rudraprayag & 55 & 4405 & 2002 & 428 & 21 \\
\hline 8 & Almora & 145 & 4293 & 5554 & 1241 & 22 \\
\hline 9 & Bageshwar & 52 & 4998 & 1704 & 482 & 28 \\
\hline 10 & Pithoragarh & 107 & 4518 & 4385 & 1882 & 43 \\
\hline 11 & Champawat & 60 & 4327 & 2193 & 605 & 28 \\
\hline 12 & Nainital & 258 & 3700 & 15255 & 15623 & 43 \\
\hline 13 & Usnagar & 333 & 4952 & 13889 & 26319 & 112 \\
\hline
\end{tabular}

Source: State Level Bankers Committee, Uttarakhand (2019)

In case of PMJDY from 28 August, 2014 till 31 Dec, 2019 26,74,654 accounts have been opened of which about 21,07,759 (78.08\%) have been issued Rupay debit card. While about 20,04,032 (82.12\%) were linked with Aadhar card. In case of advances to agriculture, to weaker sections and females the financial inclusion has enhanced in past few years and is at par to National standards.

\section{(ii) In Hill rural region of Uttarakhand}

A particular region could be deprived of various facets be it social, economic or other. Various external factors works to create such deprivation and to deprive a region of it. But often mainly in the case of underdeveloped region the area is deprived not only because of the external factors but due to the characteristics of the region itself. This reflects the concept of area deprivation which is largely associated with the hill rural regions of Uttarakhand state. The hill rural regions are marked with issues of poor geographical location which leads to make them unfit for industrial development and further the same geographical settings inhibits the agriculture development in these regions. The existence of underdevelopment, poverty and lack of income and employment opportunities has not only led to the creation of economic deprivation but also has lead to social deprivation in these regions. The following table 2 depicts the state of financial inclusion in Uttarakhand. The analysis of the data reflecting the penetration of banking indicates higher banking coverage among Dehradun district in terms of bank branches per households while in case of bank branches per population average it is good in case of Rudraprayag district. The Cash deposit ratio is high in case of rural areas of Udham Singh nagar, Chamoli and Hardwar district. The priority sector normally depends on Cash deposit ratio and higher it is, higher will be the financial flow towards priority sector lending. This causation is noticed in case of Hardwar and Udham Singh Nagar where priority sector lending is higher both in terms of amount and number in agriculture, housing and education sector. In case of Dehradun while CD ratio is less but priority sector lending is relatively higher in this district. 
Table 2: State of financial inclusion in rural areas of Uttarakhand

\begin{tabular}{|c|c|c|l|l|l|l|c|c|}
\hline $\begin{array}{l}\text { S. } \\
\text { No }\end{array}$ & District Name & $\begin{array}{c}\text { Bank } \\
\text { branch per } \\
\text { Rural } \\
\text { households }\end{array}$ & $\begin{array}{l}\text { Bank } \\
\text { branch per } \\
\text { average } \\
\text { population }\end{array}$ & $\begin{array}{l}\text { Rural } \\
\text { Bank } \\
\text { branches }\end{array}$ & $\begin{array}{l}\text { Deposit } \\
\text { in crore }\end{array}$ & $\begin{array}{l}\text { Advances } \\
\text { (in crore) }\end{array}$ & $\begin{array}{l}\text { C:D } \\
\text { Ratio }\end{array}$ & $\begin{array}{l}\text { PSA (in } \\
\text { Crore) }\end{array}$ \\
\hline 1 & Dehradun & 873 & 4574 & 165 & 6291 & 1890 & 31 & 1548 \\
\hline 2 & Uttarakashi & 1510 & 7458 & 41 & 1140 & 463 & 41 & 346 \\
\hline 3 & Haridwar & 2272 & 13303 & 90 & 4665 & 4245 & 91 & 2115 \\
\hline 4 & Tehri & 1218 & 5776 & 95 & 3061 & 684 & 22 & 418 \\
\hline 5 & Pauri & 1064 & 4488 & 128 & 4153 & 813 & 20 & 453 \\
\hline 6 & Chamoli & 1109 & 4958 & 67 & 2465 & 2235 & 91 & 258 \\
\hline 7 & Rudraprayag & 942 & 4302 & 54 & 1934 & 419 & 22 & 217 \\
\hline 8 & Almora & 1252 & 5601 & 100 & 3376 & 586 & 17 & 367 \\
\hline 9 & Bageshwar & 1097 & 4918 & 51 & 1652 & 464 & 28 & 228 \\
\hline 10 & Pithoragarh & 1276 & 5445 & 76 & 2456 & 1102 & 45 & 428 \\
\hline 11 & Champawat & 1040 & 5030 & 44 & 1688 & 406 & 24 & 212 \\
\hline 12 & Nanital & 1026 & 5204 & 112 & 3692 & 1159 & 31 & 1228 \\
\hline 13 & Usnagar & 1683 & 9001 & 118 & 3082 & 3083 & 100 & 2225 \\
\hline
\end{tabular}

Source: State Level Bankers Committee, Uttarakhand (31 Dec, 2019)

\section{Literature Review}

The concept of financial inclusion in literature has different definitions but they all seem to have similar information content and therefore tend to put across the same meaning. The Government of India's Committee on Financial Inclusion in India begins its report by defining financial inclusion as the process of ensuring access to financial services and timely and adequate credit where needed by vulnerable groups such as the weaker sections and low income groups at an affordable cost (Rangarajan Committee 2008). RBI (2008) defines Financial Inclusion as "process of ensuring access to appropriate financial products and services needed by all sections of the society in general and vulnerable groups such as weaker sections and low income groups in particular." Chakraborty (2011) states that "Financial inclusion is the process of ensuring access to appropriate financial products and services needed by all sections of society including vulnerable groups such as weaker sections and low income groups at an affordable cost in a fair and transparent manner by mainstream institutional players." Sarma (2008), states that financial inclusion is the process that ensures the ease of access, availability, and usage of formal financial system for all members of an economy. World Bank (2014) defines financial inclusion as the way financially excluded and underserved people in a society have access to a range of available financial services without any discrimination.

The Measure of financial inclusion depends on the way it is defined; it is customized as per the requirement with regards to people, place and income (Kunt \& Klapper, 2012). Some studies have measured financial inclusion by the proportion of population with access to financial services especially the people having a bank account. It is not viable to collect the data from number of bank accounts opened in a particular region because it can only be obtained through nation-wide surveys, besides it is difficult to conduct studies based on survey data. (Sriram \& Sundaram, 2015). It is not so easy to measure the financial inclusion because of its inadequate evidence and the use of financial services by households and firms are found to be limited (Claessens, 2006). 
Various studies (Sarma, 2008a, 2010b, 2012; Gupte et al., 2012; Singh et al., 2014; Laha and Kuri, 2014; Laha, 2015; Ambarkhane et al., 2014; Raichoudhury, 2016) have calculated Financial Inclusion Index on the basis of following dimensions: banking penetration, availability banking services and usages of banking services). IFI is computed by using a multidimensional approach, similar to that used by UNDP for computing HDI, HPI and GDI etc. CRISIL in 2013 launched an index to measure the status of financial inclusion in India. CRISIL Inclusix is a relative index on a scale of 0 to 100 , and combines three critical parameters of basic banking servicesbranch penetration, deposit penetration, and credit penetration - into one metric.

On the other hand Financial Inclusion Index has been calculated through other methods. Chakravarty and Pal (2013) in their study of Indian states (1972 to 2009) calculated financial inclusion through axiomatic method. Some other studies carried out by (Bagil and Dutta, 2012; Lenka and Sharma, 2017) have utilised PCA method to calculate the Financial Inclusion Index.

\section{Need of the study}

Financial inclusion in the present time should enhance its outreach to the most deprived and secluded group of population in the country residing in the regions which are associated with the concept of "Area Deprivation". This targeted outreach could be attained only when the level of financial inclusion is correctly assessed mainly through primary survey in such regions. Thus the present study will help in evaluating and assessing the correct picture of financial inclusion in the hill rural regions of Uttarakhand region. The study will help to understand the level of FII in Hill rural areas in comparison to the FII of rural India. Further there is a need of identifying different dimensions and parameters for calculating Financial Inclusion Index for such reasons because of three reasons: firstly, as the study is completely based on primary data and does not entertains the secondary data as done largely my majority of the studies, secondly, as the hill rural regions holds unique characteristics and issues in comparison to that of other rural regions of the country and thirdly since the population of such regions deals largely with the major problem of poverty, lack of income and employment opportunities. The financial inclusion should consider the insertion of these aspects along with the variables which are basic universal prerequisite for financial inclusion.

Further it is important to mention that the financial inclusion has enhanced with opening of bank accounts in the Uttarakhand state and also in the hill rural areas of Uttarakhand but still its impact has not been felt in the these regions. These regions are still dealing with the issue of migration which is further accentuated due to the surmounting problems of lack of income and employment opportunities and lack of adequate infrastructure for promotion of entrepreneurship development and support to farming. In the present context the infrastructure refers to the financial structure which supports the credit flow by enhancing its accessibility and easing its delivery process mainly under priority sector lending. Thus the increase in financial inclusion and its failure in bringing expected change demand the review of FII (Financial Inclusion Index) in terms of new perspective and new indicators.

\section{Objectives of the Study}

- To identify the parameters to compute Financial Inclusion Index based on dimensions which are more critical and further supports in the sustainable economic development of rural community mainly residing in deprived, secluded and neglected region of the country.

- To assess the level of Financial Inclusion Index in the hill rural region of Uttarakhand vis-à-vis FII of All India Rural households.

- To identify the inter-development block variation within the development blocks of hill rural region of Uttarakhand state 


\section{Study Area}

Uttarakhand state comprises of 13 districts out of which 10 districts are designated as hill districts while other three are denominated as plain area districts. The present study was conducted in the rural regions of three hill districts of Uttarakhand, which are Pauri Garhwal, Chamoli and Rudraprayag. Pauri Garhwal is one of the largest districts among all three and comprises of 15 development blocks while Chamoli has 9 development blocks and Rudraprayag has 3 blocks. Due to hilly and sub-Mountain topography of these regions the arable land is less in the study area. But still agriculture is largely carried out, largely for self-consumption. Flora of these districts includes a vast range varying from subtropical to alpine species owing to the variation in altitude and aspects. The large, medium and small scale industries are not located in these regions. Village, cottage, home based industries are very marginal in number. Industrial structure of these regions is mainly based on utilization of forest produce and other local raw materials. The hill rural regions of all three districts are resource

\begin{tabular}{|c|l|c|l|}
\hline Parameters & \multicolumn{1}{|c|}{ Parameters } & Dimension & \multicolumn{1}{c|}{ Dimension/Significance } \\
\hline (P1) & $\begin{array}{l}\text { Percentage of household } \\
\text { having bank account (at } \\
\text { the time of survey) }\end{array}$ & (D1) & $\begin{array}{l}\text { Banking Penetration: Indicates the bank } \\
\text { penetration and usage by community }\end{array}$ \\
\hline (P2) & $\begin{array}{l}\text { Percentage of households } \\
\text { doing digital payments } \\
\text { (Done in past few months } \\
\text { from the date of survey) }\end{array}$ & (D2) & $\begin{array}{l}\text { Usage of ICT in availing banking services: It } \\
\text { indicates the usage of digital financial services } \\
\text { which been recognized as an innovative and } \\
\text { effective means to achieve financial inclusion } \\
\text { by providing new financial services to } \\
\text { excluded people and reflects the inclusion of } \\
\text { rural community in such form of digital } \\
\text { transaction environment. }\end{array}$ \\
\hline (P3) & $\begin{array}{l}\text { Percentage of households } \\
\text { having outstanding loans } \\
\text { (at the time of survey) }\end{array}$ & $\begin{array}{l}\text { Percentage of households } \\
\text { having Insurance (at the } \\
\text { time of survey) }\end{array}$ & $\begin{array}{l}\text { Credit Penetration: The dimension depicts the } \\
\text { level of credit penetration in the rural areas } \\
\text { along with access to credit facilities }\end{array}$ \\
\hline (P4) & $\begin{array}{l}\text { Social Security penetration: This indicator not } \\
\text { only depicts the level of penetration and usage } \\
\text { of essential financial services but also depicts } \\
\text { the level of social security the financial } \\
\text { services have succeeded to provide }\end{array}$ \\
\hline
\end{tabular}

All the four dimensions are equally important in context of financial inclusion mainly in case of rural areas and equal weights are assigned for each of the dimensions. The assigning of equal weight deprived and face the problems of huge migration due to lack of employment opportunities.

\section{Research Methodology}

\section{(i) Data sources and approach}

Stratified multi-stage random sampling method was utilized for the present study to extract the sample of 13 development block, 78 villages and 780 rural households. Primary data has been collected through the use of questionnaires and interview method.

The study is completely based on the primary data collected in the survey carried out from the month of December, 2019 to August, 2020. The study has selected four major indicators of financial inclusion which defined our four dimensions of the study for calculating Financial Inclusion Index. The four dimensions of the study are as follows: 
was difficult to assign weights for NABARD study due to unavailability of complete data set of the survey. So to maintain uniformity to facilitate comparison, equal weights were assigned to all the dimensions. The other limitation that comes out of this comparison between All Indian rural household data and households of hill rural regions is of the time gap. The All India rural household survey was conducted in year 2016-17 by NABARD while the survey of households of hill rural regions of Uttarakhand was conducted in 2019-20 session. But even then we could not deny that the results from the present study will not be indicative of the correct status of FII in hill rural households in comparison to that of households of rural India.

The possession of bank account is the basic prerequisite of financial inclusion while the usage of digital transactions is also equally important for not only providing the benefits of financial services to the secluded regions such as hill rural regions of Uttarakhand but also to solve the issue of physical accessibility of financial institutions for availing different facilities. In recent years, MFS have been recognized as an innovative and effective means to achieve financial inclusion by providing new financial services to excluded people (Sihvonen, 2006). Further the possession of outstanding loan is equally important in terms of assessing the benefits of financial inclusion through promoting investment and entrepreneurship in such regions which are deprived of income and employment opportunities. The possession of insurance holds equal importance in content of these regions which requires social security benefits. Thus all the four dimensions are equally important for demarking the financial inclusion level mainly in the secluded, neglected and resource deprived regions of the country.

\section{(ii) Method}

Financial Inclusion Index (FII) in the present study has been computed by using a multidimensional approach. The same approach was utilized by UNDP for computing Human development index. In the first stage of calculating the index the dimensions are selected which will utilized for calculating FII thereafter a dimension index is calculated for each dimension of financial inclusion.

$$
\text { Formula 1: } d i=w i * \frac{A i-m i}{M i-m i}
$$

Where

$w i=$ Weight attached to the dimension $\mathrm{i}, 0 \leq$ wi $\leq 1$;

Higher the value of di, higher the achievement in dimension $\mathrm{i}$.

$$
\begin{aligned}
& A i=\text { Actual value of dimension } \mathrm{i}_{;} \\
& m i=\text { Minimum value of dimension } \mathrm{i}_{;} \\
& M i=\text { Maximum value of dimension } \mathrm{i}_{;} \\
& d i=\text { Dimensions of financial inclusion } \mathrm{i} \text {. }
\end{aligned}
$$

Formula (1) confirms that $0 \leq w i \leq 1$ and here, dimensions of financial inclusion represented by a point $X=(1,2,3 \ldots)$. Point $0=(0,0,0 \ldots 0)$ represents the point indicating the worst situation and Point $\mathrm{W}=$ $(1,2,3 \ldots)$ represents an ideal situation. Here, both the worst point 0 and the ideal point $\mathrm{W}$ is the important factor to calculate an index for countries' and states which indicates the position of financial inclusion. If the distance will be larger between $\mathrm{X}$ and 0 then it represents higher financial inclusion and similarly if the distance will be lower between $\mathrm{X}$ and 0 then it represents lower financial inclusion.

Formula 2:

$$
x_{1}=\frac{\sqrt{d_{1}^{2}+d_{2}^{2}+d_{3}^{2}+\cdots \cdots+d_{n}^{2}}}{\sqrt{w_{1}^{2}+w_{2}^{2}+w_{3}^{2}+\cdots \cdots+w_{n}^{2}}}
$$

Formula 3:

$$
X_{2}=1-\frac{\sqrt{\left(w_{1}-d_{1}\right)^{2}+\left(w_{2}-d_{2}\right)^{2}+\left(w_{3}-d_{3}\right)^{2}+\cdots+\left(w_{n}-d_{n}\right)^{2}}}{\sqrt{\left(w_{1}^{2}+w_{2}^{2}+w_{3}^{2}+\cdots \ldots \ldots+w_{n}^{2}\right)}}
$$


Formula 4:

$$
F I I=\frac{1}{2}\left(\mathrm{X}_{1}+\mathrm{X}_{2}\right)
$$

The formula (2), for Financial Inclusion Index (FII), $\mathrm{X}_{1}$ indicates average of the Euclidian distance between $\mathrm{X}$ and 0 . Higher value of $X_{l}$ implies more financial inclusion. Formula (3), for FII, $X_{2}$ indicates inverse Euclidian distance between $\mathrm{X}$ and $\mathrm{W}$ and similarly, higher value of $X_{2}$ corresponds to be higher financial inclusion. The formula (4) is the simple average of $X_{1}$ and $X_{2}$. (Sethy, S.K, 2016).

Depending on the value of FII, the hill rural region of the state will be categorized into

1. $0.6<$ FII $\leq 1$ indicates high financial inclusion

2. $0.4<$ FII $<0.6$ indicates medium financial inclusion

3. $0 \leq$ FII $<0.4$ indicates low financial inclusion

The study with the help of the four dimensions has come up with the FII for all three hill districts and within the blocks in these districts. To make the comparison in the FII within the population the study has presented the readjusted values of the FII in terms of three aspects (a) Average value of FII in given population (b) Maximum value of FII in given population and (c) FII value of India Rural households

\section{Empirical Result and Discussion}

The demographic profile of the households indicates the inclusion of the households representing different socio-economic categories of the population. Following are the results of the study which are presented in the output table representing the absolute value of FII along with adjusted value of FII assuming average FII value and Maximum value of the give population as the base value along with All India FII value the base value.

Table 3: Demographic status of the hill rural households

\begin{tabular}{|c|c|c|c|}
\hline $\begin{array}{l}\text { Demographic } \\
\text { profile }\end{array}$ & Variable & Frequency & Percent \\
\hline \multirow{4}{*}{ Caste } & Gen & 479 & 61.4 \\
\hline & OBC & 17 & 2.2 \\
\hline & $\mathrm{SC}$ & 252 & 32.3 \\
\hline & ST & 32 & 4.1 \\
\hline \multirow{3}{*}{ Income Status } & Antodaya & 20 & 2.6 \\
\hline & BPL & 407 & 52.2 \\
\hline & APL & 353 & 45.3 \\
\hline \multirow[t]{2}{*}{ Family head } & Female headed household & 199 & 25.5 \\
\hline & Male headed hsouehold & 581 & 74.5 \\
\hline \multirow{4}{*}{ Status of house } & No house & 1 & .1 \\
\hline & Kaccha & 89 & 11.4 \\
\hline & Semi-Kaccha & 115 & 14.7 \\
\hline & Paccha & 575 & 73.7 \\
\hline \multirow{5}{*}{$\begin{array}{l}\text { Primary source of } \\
\text { Income }\end{array}$} & Agriculture & 227 & 29.1 \\
\hline & Non-agriculture & 196 & 25.1 \\
\hline & Self employment other than agriculture & 77 & 9.9 \\
\hline & Transfer Payments & 240 & 30.8 \\
\hline & Remittances & 40 & 5.1 \\
\hline
\end{tabular}

Source: ICSSR-IMPRESS-R.P., Primary Survey 2019-20 
Table 4 (a): Value of Indicators of different Dimensions of FII (All India Rural household)

\begin{tabular}{|c|c|c|c|c|c|c|}
\hline \multirow[t]{2}{*}{ S. No } & \multirow[t]{2}{*}{$\begin{array}{l}\text { Survey conducted } \\
\text { by }\end{array}$} & \multirow[t]{2}{*}{$\begin{array}{c}\text { Survey } \\
\text { population }\end{array}$} & \multicolumn{4}{|c|}{$\begin{array}{c}\text { Value of Parameters indicating different } \\
\text { dimensions }\end{array}$} \\
\hline & & & $\begin{array}{c}\text { Bank } \\
\text { A/c }(\mathbf{P 1})\end{array}$ & $\begin{array}{c}\text { Digital } \\
\text { Payment } \\
\text { (P2) }\end{array}$ & $\begin{array}{c}\text { Insurance } \\
\text { (P3) }\end{array}$ & $\begin{array}{l}\text { Outstanding } \\
\text { Loan (P4) }\end{array}$ \\
\hline 1 & $\begin{array}{c}\text { NABARD All } \\
\text { India Rural } \\
\text { Financial Inclusion } \\
\text { Survey 2016-17 }\end{array}$ & $\begin{array}{c}\text { Rural } \\
\text { households in } \\
\text { India }\end{array}$ & 0.881 & 0.236 & 0.474 & 0.25 \\
\hline
\end{tabular}

Source: All India Rural Financial Inclusion Survey 2016-17, NABARD Authors' Computation

Table 4 (b)): Value of different Dimensions and FII (All India Rural households)

\begin{tabular}{|c|c|c|c|c|c|c|c|c|}
\hline S. No & $\begin{array}{c}\text { All India Rural } \\
\text { household } \\
\text { survey }\end{array}$ & \multicolumn{2}{|c|}{ Dimension value for each Parameter } & X1 & X2 & FII \\
\cline { 3 - 6 } & & D1 & D2 & D3 & D4 & & & \\
\hline 1 & Overall & 0.22025 & 0.059 & 0.1185 & 0.0625 & 0.53 & 0.40 & 0.46 \\
\hline
\end{tabular}

The value of different dimensions and FII for all India Rural households is computed to readjust the FII values of different blocks of Hill rural regions of Uttarakhand to make it fit for comparison. The value of FII calculated on the basis of All India Rural household's survey indicates the medium level of financial inclusion in case of rural households in India. Among all the four indicators the primary survey indicates better results in case of first indicator which is percentage of rural household with bank account. The study shows that every household in hill rural region of Uttarakhand holds a bank account. On the contrary the results are poor in case of other three indicators with holding of outstanding loan (at the time of survey) showing the lowest performance.

Table 5 (a)): Value of Indicators of different Dimensions of FII (Development blocks of 3 districts)

\begin{tabular}{|c|c|c|c|c|c|c|}
\hline S. No & District Name & \multirow{2}{*}{ Block name } & \multicolumn{3}{|c|}{ Value of Parameters indicating different dimensions } \\
\cline { 4 - 7 } & & & $\begin{array}{c}\text { Bank } \\
\mathbf{A} / \mathbf{c} \\
(\mathbf{P 1})\end{array}$ & $\begin{array}{c}\text { Digital } \\
\text { Payment } \\
(\mathbf{P 2})\end{array}$ & $\begin{array}{c}\text { Insurance } \\
(\mathbf{P 3})\end{array}$ & $\begin{array}{c}\text { Outstanding } \\
\text { Loan (P4) }\end{array}$ \\
\hline 1 & Rudraprayag & Jakholi & 1 & 0.2 & 0.32 & 0.15 \\
\hline 2 & Rudraprayag & Ukhimath & 1 & 0.07 & 0.33 & 0.05 \\
\hline 3 & Chamoli & Pokhari & 1 & 0.18 & 0.25 & 0.13 \\
\hline 4 & Chamoli & Karanprayag & 1 & 0.17 & 0.37 & 0.08 \\
\hline 5 & Chamoli & Gairsain & 1 & 0.4 & 0.43 & 0.05 \\
\hline 6 & Chamoli & Ghat & 1 & 0.28 & 0.43 & 0.01 \\
\hline 7 & Pauri & Pauri & 1 & 0.167 & 0.35 & 0 \\
\hline 8 & Pauri & Kot & 1 & 0.167 & 0.33 & 0 \\
\hline 9 & Pauri & Kaljikhal & 1 & 0.15 & 0.283 & 0 \\
\hline 10 & Pauri & Khirsu & 1 & 0.267 & 0.25 & 0 \\
\hline 11 & Pauri & Pabao & 1 & 0.217 & 0.167 & 0 \\
\hline 12 & Pauri & Thalisain & 1 & 0.183 & 0.133 & 0 \\
\hline 13 & Pauri & Ekeshwar & 1 & 0.283 & 0.03 & 0.017 \\
\hline
\end{tabular}

Source: ICSSR-IMPRESS-R.P., Primary Survey 2019-20 
Table: 5 (b) Value of different Dimensions and FII (Development blocks representing hill rural region of 3 districts)

\begin{tabular}{|c|c|c|c|c|c|c|c|c|c|}
\hline \multirow{2}{*}{ S. No } & \multirow{2}{*}{$\begin{array}{c}\text { District } \\
\text { Name }\end{array}$} & \multirow{2}{*}{ Block name } & \multicolumn{3}{|c|}{ Dimension value for each Parameter } & X1 & X2 & FII \\
\cline { 4 - 8 } & & D1 & D2 & D3 & D4 & & & \\
\hline 1 & Chamoli & Gairsain & 0.25 & 0.1 & 0.1075 & 0.0125 & 0.58 & 0.37 & 0.48 \\
\hline 2 & Chamoli & Ghat & 0.25 & 0.07 & 0.1075 & 0.0025 & 0.56 & 0.32 & 0.44 \\
\hline 3 & Rudraprayag & Jakholi & 0.25 & 0.05 & 0.08 & 0.0375 & 0.54 & 0.32 & 0.43 \\
\hline 4 & Chamoli & Karanprayag & 0.25 & 0.0425 & 0.0925 & 0.02 & 0.54 & 0.30 & 0.42 \\
\hline 5 & Chamoli & Pokhari & 0.25 & 0.045 & 0.0625 & 0.0325 & 0.53 & 0.29 & 0.41 \\
\hline 6 & Pauri & Pauri & 0.25 & 0.04175 & 0.0875 & 0 & 0.53 & 0.27 & 0.40 \\
\hline 7 & Pauri & Kot & 0.25 & 0.04175 & 0.0825 & 0 & 0.53 & 0.27 & 0.40 \\
\hline 8 & Pauri & Khirsu & 0.25 & 0.06675 & 0.0625 & 0 & 0.53 & 0.28 & 0.40 \\
\hline 9 & Rudraprayag & Ukhimath & 0.25 & 0.0175 & 0.0825 & 0.0125 & 0.53 & 0.26 & 0.39 \\
\hline 10 & Pauri & Kaljikhal & 0.25 & 0.0375 & 0.07075 & 0 & 0.53 & 0.25 & 0.38 \\
\hline 11 & Pauri & Pabao & 0.25 & 0.05425 & 0.04175 & 0 & 0.52 & 0.24 & 0.38 \\
\hline 12 & Pauri & Thalisain & 0.25 & 0.04575 & 0.03325 & 0 & 0.51 & 0.22 & 0.37 \\
\hline 13 & Pauri & Ekeshwar & 0.25 & 0.07075 & 0.0075 & 0.00425 & 0.52 & 0.22 & 0.37 \\
\hline
\end{tabular}

Source: ICSSR-IMPRESS-R.P., Primary Survey 2019-20, and authors' computation

Table 5 (C): Value of different Dimensions and readjusted values of FII based on 3 criteria (Development blocks representing hill rural region of 3 districts)

\begin{tabular}{|c|c|c|c|c|c|c|}
\hline $\begin{array}{c}\text { S } \\
\text { No }\end{array}$ & $\begin{array}{c}\text { District } \\
\text { Name }\end{array}$ & $\begin{array}{c}\text { Block } \\
\text { Name }\end{array}$ & FII & $\begin{array}{c}\text { FII value } \\
\text { readjusted } \\
\text { assuming } \\
\text { average FII } \\
\text { value as the base } \\
\text { value }\end{array}$ & $\begin{array}{c}\text { FII value } \\
\text { readjusted } \\
\text { assuming } \\
\text { Maximum value } \\
\text { of FII as the base } \\
\text { value }\end{array}$ & $\begin{array}{c}\text { FII value } \\
\text { readjusted } \\
\text { assuming All } \\
\text { India Rural FII } \\
\text { value as the base } \\
\text { value }\end{array}$ \\
\hline 1 & Chamoli & Gairsain & 0.48 & 118.4 & 100 & 104.35 \\
\hline 2 & Chamoli & Ghat & 0.44 & 108.53 & 91.667 & 95.652 \\
\hline 3 & Rudraprayag & Jakholi & 0.43 & 106.07 & 89.583 & 93.478 \\
\hline 4 & Chamoli & Karanpraya & 0.42 & 103.6 & 87.5 & 91.304 \\
\hline 5 & Chamoli & Pokhari & 0.41 & 101.13 & 85.417 & 89.13 \\
\hline 6 & Pauri & Pauri & 0.40 & 98.668 & 83.333 & 86.957 \\
\hline 7 & Pauri & Kot & 0.40 & 98.668 & 83.333 & 86.957 \\
\hline 8 & Pauri & Khirsu & 0.40 & 98.668 & 83.333 & 86.957 \\
\hline 9 & Rudraprayag & Ukhimath & 0.39 & 96.201 & 81.25 & 84.783 \\
\hline 10 & Pauri & Kaljikhal & 0.38 & 93.735 & 79.167 & 82.609 \\
\hline 11 & Pauri & Pabao & 0.38 & 93.735 & 79.167 & 82.609 \\
\hline 12 & Pauri & Thalisain & 0.37 & 91.268 & 77.083 & 80.435 \\
\hline 13 & Pauri & Ekeshwar & 0.37 & 91.268 & 77.083 & 80.435 \\
\hline
\end{tabular}

Source: Authors' Computation based on ICSSR-IMPRESS-R.P., Primary Survey 2019-20 and All India Rural Financial Inclusion Survey 2016-17

The result indicates the lower level of financial inclusion in case of majority of development blocks representing hill rural areas of the three districts. The results depicting this lower level of 
FII in these regions of Uttarakhand is further confirmed with the help of the comparison of these FII values with that of the FII value computed for all India rural households. The comparison reveal that almost all the development blocks have FII less than that of the FII value computed for all India rural households.

The results indicates that Financial Inclusion Index in almost every development block of hill rural regions (except in case of Gairsain development block of Chamoli district) is lower than that of the FII of all India rural households. The study further indicates towards larger incidence of lower FII in hill rural areas under development blocks of district Pauri of Uttarakhand. In the light of these facts it is important to mention that Pauri is one of the two districts of Uttarakhand state which have shown negative decadal population growth as per 2011 census. The study further shows the higher degree of variability in FII between the rural regions of various development blocks of hill districts. The hill rural regions under development block of Chamoli have comparatively higher level of financial inclusion than that of the Pauri and Rudraprayag districts.

\section{Conclusion}

The comparative analysis of the FII of households of hill rural regions of Uttarakhand and FII of all India rural households indicate a concerning picture regarding the higher level of financial exclusion among these hills rural regions of the state. This concern is based on the fact that these are the regions of the Uttarakhand state which are largely marked with issues of lack of income and employment opportunities, poverty, poor agriculture status, lack of medium and large industrialization due to geographical constraints and poor infrastructure which all culminates towards aggravating the issue of poverty and large scale migration from these regions. Entrepreneurship development, increase in investment and hence employment opportunities could be the solution for dealing with these issues of hill rural regions. Further these solutions could be achieved through decreasing the gap between the financial institutions and these households. Increase in credit flow, easing the accessibility to credit, easing the banking process with promotion of digital payments and enhancing the outreach of insurance facility to increase the social security net could assist in overall development of these regions of the state in the long run.

\section{Acknowledgement}

This study is the part of the research project (2019-20) sponsored by Indian Council of Social Science Research, New Delhi under IMPRESS Scheme, MHRD. The financial support is thankfully acknowledged.

\section{References}

Ambarkhane D, Singh AS and Venkataramani B (2014) "Measuring financial inclusion of Indian states", Int. J Rurall Manag. 12 (1): 72-100.

Bagil S and Dutta P (2012) "A study of financial inclusion in India", Journal of Radix International Educational and Research Consortium, 8(1)

Chakrabarty KC (2011) Financial Inclusion: A Road India Needs to Travel, RBI Bulletin, November, 2011.

Gupte R, Venkataramani B and Gupta D (2012) "Computation of financial inclusion index for India", Procedia-Social and Behavioral Sciences, 37:133-149.

Kapur R and Reddy R (2020) Financial inclusion in rural India: Banking and ATM sector in India, Grant Thornton LLP

Kunt A and Klapper LF (2012) Measuring financial inclusion: The global findex database. World Bank Policy Research Working Paper, (6025).

Laha A and Kuri, PK (2014) "Demand for and supply of financial inclusion in India: an inter-state analysis", ELK Asia Pacific J. Fina.Ris. Man. 5 (1): 103-116.

Laha A (2015) "Association between financial inclusion and human development in South Asia: a cross- country analysis with special reference to India", J. Eco. Poli. Res. 10(2): 69-91. 
Lenka, SK and Sharma R (2017) "Does financial inclusion spur economic growth in India?" The J. Dev. Areas, 51(3): 215-228

Sriram M and Sundaram N (2015) Financial Inclusion Index: A Customized Regional Model with Reference to Economically Most Backward Districts of Tamil Nadu, India, Medit. J. Soc. Sci. 6(6)

Raichoudhury A (2016) "Financial inclusion \& human development: a cross country analysis", Asian J. Busin. Res.6(1): 34-48.

RBI. (2008) Report of the Committee on Financial Inclusion, Jan 2008, Reserve Bank of India.

Sarma M (2008) "Index of financial inclusion", ICRIER Working paper no. 215.

Sarma M (2010) "Index of financial inclusion", Discussion Papers in Economics, CITD, JNU, New Delhi.

Sarma M (2012) "Index of financial inclusion - a measure of financial sector inclusiveness", Berlin Working papers on Money, Finance, Trade and Development, No. 7.

Sarma M (2008) Index of Financial Inclusion. Indian Council for Research on International Economic Relations Working Paper No. 215.

Sethy SK (2016) Developing a financial inclusion index and inclusive growth in India, Theor. Appl. Eco.XXIII 2(607): 187-206

Sihvonen M (2006) Ubiquitous financial services for developing countries. The Elect. J. Info. Syst. Dev. Countries, 28(1):1-11.

Singh C, Mittal A, Goenka A, Goud CP, Ram K, et al., (2014), "Financial inclusion in India: select issues", IIMB-WP N0. 474: 1-43.

State Level Bankers Committee (2019) 72 Review meeting Report, Dehradun, Uttarakhand

World Bank (2014) Global financial development report 2014: Financial Inclusion. Washington, DC.

$* * * * * * * * *$ 